\title{
Spatial and temporal variation in cumulative mass eroded and organic matter percentage in surface sediments near areas of active salmon aquaculture
}

\author{
B. A. Law $^{1,2, *}$, P. S. Hill ${ }^{2}$ \\ ${ }^{1}$ Fisheries and Oceans Canada, Bedford Institute of Oceanography, Dartmouth, Nova Scotia B2Y 4A2, Canada \\ ${ }^{2}$ Department of Oceanography, Dalhousie University, Halifax, Nova Scotia B3H 4J1, Canada
}

\begin{abstract}
Cores collected with an intact sediment-water interface were coupled to a Gust erosion chamber to measure cumulative mass eroded at increasing shear stress steps in areas of salmon aquaculture. Cores were collected along transects of stations at a cohesive and a noncohesive seabed site. Organic matter percentage in bottom sediments near aquaculture sites ( $<200 \mathrm{~m}$ from operations) correlated with the cumulative mass eroded. As the percentage of organics increased, the mass eroded decreased over the sampling periods. Two-way ANOVA indicated that a significant increase $(p<0.05)$ in organic matter percentage in bottom sediments occurred at both sites over the times of the sampling, which were coincident with the periods from when the aquaculture sites were first stocked with salmon smolt until just before fish were removed for market. Along the sampled transect at the cohesive site, the percentage of organic matter in bottom sediment increased significantly out to $200 \mathrm{~m}$ from the site. At the non-cohesive site, organic matter percentage in the sediment only increased at locations that were immediately adjacent to the cage site. Organic matter flux in $\mathrm{kg} \mathrm{m}^{-2} \mathrm{~d}^{-1}$ doubled over the time of the study at both sites and values suggest that material would have been available for resuspension and transport from both sites. The ability to parameterize the movement of this material in transport models will increase predictive capacity regarding dispersal of farm wastes, which may help to increase the environmental sustainability of salmon aquaculture in the marine environment.
\end{abstract}

KEY WORDS: Aquaculture $\cdot$ Erosion $\cdot$ Waste transport $\cdot$ Bottom substrate

\section{INTRODUCTION}

According to the United Nations Food and Agriculture Organization, by 2015 one-third of the world's fish stocks were overfished, three-fifths were fished at maximally sustainable levels, and only two-fifteenths, or $7 \%$, of stocks were underfished (FAO 2018). These estimates indicate that capture fisheries production has little room to grow to meet the demand of the world for fish. As a result, aquaculture production continues to experience rapid growth. Between 2011 and 2016, for example, global capture fisheries production remained steady at around 90 million t per annum, while aquaculture production, excluding

\footnotetext{
*Corresponding author: brent.law@mar.dfo-mpo.gc.ca
}

aquatic plants, increased from just under 62 million to 80 million $t$ over the same period (FAO 2018).

Since 2013, salmon and trout have been the most valuable global fish commodity, and most of the salmon consumed comes from aquaculture (FAO 2018). Continuing growth in demand and value are spurring continued expansion of salmon aquaculture, but accompanying this expansion are ongoing concerns about the environmental effects of the waste products of salmon aquaculture.

Until recently, research related directly to particulate salmon aquaculture waste has dealt primarily with deposition immediately under or adjacent to net pens (Smith et al. 2005, Graydon et al. 2012, Bannister

() P. S. Hill and Fisheries and Oceans, Canada 2019. Open Access under Creative Commons by Attribution Licence. Use, distribution and reproduction are unrestricted. Authors and original publication must be credited. Publisher: Inter-Research · www.int-res.com 
et al. 2016). Modelling and field studies have focused on near-field effects from organic enrichment, while the far field has received less attention. The near field is considered to be the area within a few hundred meters of farming operations, while the far field can extend kilometers away. Models to predict the depositional footprint from salmon and other finfish farms using the settling characteristics of waste solids, approximately $40 \mathrm{~mm} \mathrm{~s}^{-1}$ for fecal material and $100 \mathrm{~mm}$ $\mathrm{s}^{-1}$ for feed pellets, have become increasingly accurate (Panchang et al. 1997, Cromey et al. 2002a,b, Chamberlain \& Stucchi 2007). Models that predict the subsequent resuspension and transport of waste material, however, are inaccurate (Chamberlain \& Stucchi 2007, Droppo et al. 2007, Reid et al. 2009). Development of coupled hydrodynamic-sediment transport models that can address the far field will require parameterization of the factors responsible for influencing the erosion of aquaculture waste material. Measurements of the erodibility of waste particles associated with finfish aquaculture, including the cumulative mass eroded (CME) at a given bottom stress, are also lacking, which limits understanding of potential farfield transport and possible environmental impacts.

Particles at the sediment-water interface move when the downstream (i.e. fluid drag) and upward (i.e. fluid lift) forces overcome the forces keeping particles in contact with the seabed (Wiberg \& Smith 1987). The critical erosion shear stress, which is denoted $\tau_{\mathrm{C}}$, is the stress required at the seabed to initiate the motion of particles (Einstein 1950, Partheniades 1962, Amos et al. 1992, Tolhurst et al. 1999). In the broadest terms, non-cohesive sediments have mean grain sizes $>63 \mu \mathrm{m}$, and cohesive sediments or 'muds' are dominated by fine-grained particles that are $<63 \mu \mathrm{m}$. Overall, there have been many investigations of the erosion of both non-cohesive (e.g. Shields 1936, Soulsby 1997) and cohesive seabeds (e.g. Winterwerp 1989, Amos et al. 1992, 1997). More recently, attention has been given to the erosion of sand-mud mixtures that show complex behaviors influenced strongly by the fraction of mud in the mixture (van Ledden et al. 2004, Stevens et al. 2007, Law et al. 2008, Wiberg et al. 2013).

The stress exerted by waves and/or currents on the seabed provides the work necessary to erode particles from the seabed, whereas particle size and density, cohesion, porosity, consolidation, and biological activity determine the erosion resistance of the seabed (Amos et al. 1992, 1997, Maa et al. 1998, Sanford \& Maa 2001, Wiberg et al. 2013). Understanding of cohesive sediment resuspension is incomplete because it is governed not only by hydrodynamic forces and the force of gravity, but also by cohesion, which depends on biological and electrochemical variables (Black et al. 2002, Droppo et al. 2007). Recent work on size sorting during the erosion of cores from the Gulf of Lions, France (Law et al. 2008) and in Seal Harbour, Nova Scotia (Milligan \& Law 2013) suggests that increases in clay content (sediment particles $<4 \mu \mathrm{m}$ in diameter) change resuspension dynamics. In sediments that contain $>10 \%$ clay, a wide range of sizes are eroded at reduced but equal rates. Sediments with a smaller clay fraction exhibit greater erodibility and size-selective sorting over the entire particle size range. Sediment with a small clay fraction can be winnowed of its fine fraction during erosion, but sediments with a larger clay fraction cannot. When muddy sands are eroded, the smallest sediment sizes are winnowed from the bed, essentially cleaning the sands. In contrast, when muds are eroded, size sorting is reduced substantially. In short, after deposition, sands are 'cleaned' by physical disturbance, but muds resist further sorting.

The input of fecal material and feed from salmon aquaculture can increase the amount of 'sticky organic material' and hence cohesion in the water column and in the sediments surrounding aquaculture sites. Milligan \& Law (2005) showed decadal changes in floc limit, which is a parameter derived from grain size distributions, from sediments collected in bays with intensive open-cage salmon aquaculture. The increased floc limit in bottom sediments was linked to increased organic loading, which ultimately increased flocculation and the settling of fine-grained material to the seabed (Milligan \& Law 2005). These changes were accompanied by increased sediment accumulation and an increase in organic matter in the seabed (Smith et al. 2005). Increases in deposited organic matter can also lead to the formation of microbial mats. These mats form when oxygen is depleted in the sediments and overlying water column and can become widespread in sulfide-rich waters (Grant \& Gust 1987). The formation of mats on the seabed is associated with a process known as 'biostabilization' (Neu 1994). This process occurs when organisms such as algae, fungi, and microbes, combined with exo-polymeric substances, 'glue down' or stabilize the sediment bed (Droppo et al. 2007). This process occurs rapidly in the organicenriched sediments around active aquaculture operations (Droppo et al. 2007). The addition of fine sediment to the seabed by aquaculture operations therefore has the potential to alter the texture of bed sediment and affect the erosion of bottom sediments near pens. 
This study used cores collected with an intact sediment-water interface coupled to a Gust erosion chamber to examine the effect of increasing shear stress on bottom sediments collected from areas of salmon aquaculture. Cores were collected and eroded from along a transect of stations at both a cohesive and non-cohesive seabed site. The goals of this study were to document the spatial and temporal changes in the CME of bottom sediments at 2 active salmon aquaculture sites located over different bottom substrates and to elucidate the possible mechanisms responsible for observed changes.

\section{MATERIALS AND METHODS}

\subsection{Overview}

The CME of cores collected with an intact sedimentwater interface was measured at 2 areas of active salmon aquaculture: (1) in Passamaquoddy Bay, southwest New Brunswick, Canada and (2) in Jordan Bay, southwest Nova Scotia, Canada (Fig. 1). Passamaquoddy Bay is sheltered from the outer Bay of Fundy by islands around the site, primarily Deer Island. The Navy Islands aquaculture site in Passamaquoddy Bay $\left(45^{\circ} 1.9^{\prime} \mathrm{N}, 67^{\circ} 0.4^{\prime} \mathrm{W}\right)$ is located in the

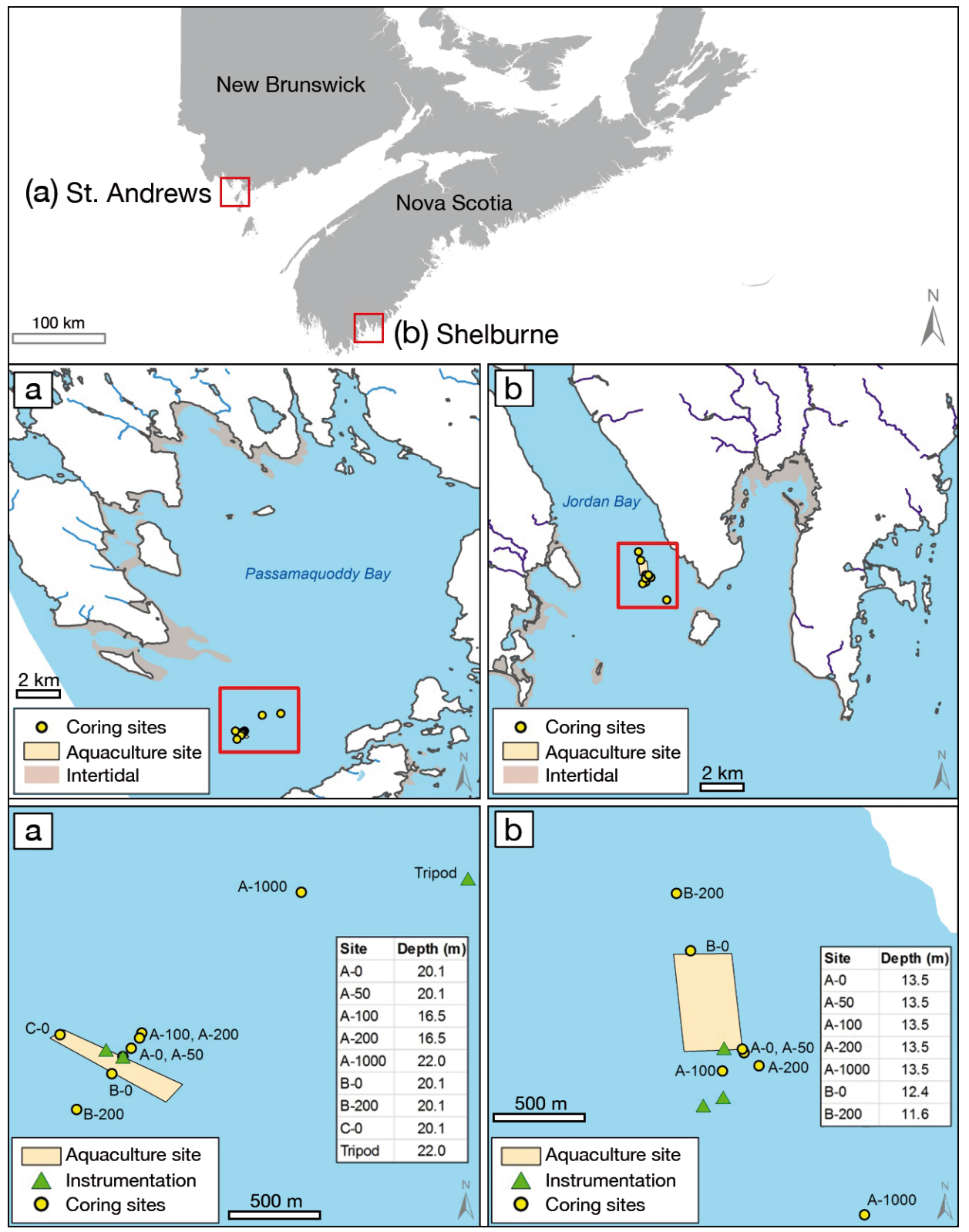

Fig. 1. The 2 study areas 
southwest corner of the Bay (Fig. 1). The average water depth at the site is approximately $23 \mathrm{~m}$ and it has an average tidal range of $7 \mathrm{~m}$ (see Fig. 3). The aquaculture site occupies an area that is about $500 \mathrm{~m}$ in length by about $200 \mathrm{~m}$ in width. It is made up of (15) circular pens in 2 parallel rows of 8 and 7 (Fig. 1). The seabed at the site is primarily mud with median diameters (d50) of approximately $9.5 \mu \mathrm{m}$ with a small sand fraction $(<2 \%)$. The sediments are cohesive, with an average clay $(<4 \mu \mathrm{m})$ fraction of greater than $20 \%$. Jordan Bay is located on the Atlantic coast of Nova Scotia and is exposed to wind waves and longer period swell. The Jordan Bay aquaculture site is located in the outer part of the Bay $\left(43^{\circ} 42.0^{\prime} \mathrm{N}\right.$, $65^{\circ} 11.7^{\prime} \mathrm{W}$ ) and is close to Blue Island (Fig. 1). The average water depth at the site is approximately $17 \mathrm{~m}$ and the average tidal range is $1.5 \mathrm{~m}$ (see Fig. 2). The aquaculture site occupies an area that is about $500 \mathrm{~m}$ in length by about $200 \mathrm{~m}$ in width. It is made up of (20) circular pens in 2 parallel rows of 10 (Fig. 1). The sediment at the site is non-cohesive. It comprises fine sand with d50 values of approximately $125 \mu \mathrm{m}$, and the clay fraction is less than $2 \%$.

The Navy Island and Jordan Bay aquaculture sites were both stocked with juvenile salmon in April and May 2015. Cores were collected and eroded, within $2 \mathrm{~h}$ or less after collection, during approximately 1 wk field excursions in May 2015, October 2015, and October 2016 at the Navy Islands site and in June 2015, September 2015, and September 2016 at the Jordan Bay site. The cores were collected using a mini-slo corer and coupled to a Gust microcosm erosion chamber. There were no visible bacterial mats on any of the eroded cores. Cores were collected along a series of stations from $0 \mathrm{~m}$ (i.e. at the cage site) to $1000 \mathrm{~m}$ (i.e. reference site) along a transect based on the mean direction of the currents at both locations. Additional stations were sampled throughout the sampling periods to encompass the opposite side of the site.

\subsection{Mini slo-corer}

The mini slo-corer is a reconfiguration of the large slo-corer developed by Bothner et al. (1998) for studies of trace metal levels associated with sewage outfalls in Boston Harbor. The mini slo-corer is a hydraulically damped gravity corer that uses $50 \mathrm{~kg}$ of lead to push a polycarbonate barrel slowly into the seabed to collect bottom core samples. The key feature of the slo-corer is its ability to collect sediment cores without disturbing the sediment-water interface, thereby preserving flocculated mobile material at the surface. Other corers (e.g. box and gravity) and grab samplers (e.g. Eckman and Van Veen) do not preserve an intact sediment-water interface due to their impact on the seabed when sampling (Milligan \& Law 2013).

\subsection{Gust chamber}

The Gust chamber is an erosion simulator that comprises a housing with a rotating stirring disk, a removable lid, and water input and output connections. It fits directly on top of a slo-core tube. By controlling both the rotation rate of the stirring disk and the rate at which water is pumped through the device, a uniform shear stress can be applied across the sediment surface. Shear stresses applied to cores for this study were $0.01,0.08,0.16,0.24,0.32,0.40$, 0.48 , and $0.60 \mathrm{~Pa}$, with the first step of $0.01 \mathrm{~Pa}$ being used to flush tubing and the Gust chamber. Shear stress at each level was maintained until an attached Hach 2100 AN turbidity meter recorded values that corresponded to near background concentrations, which usually required $30 \mathrm{~min}$ for the $0.01 \mathrm{~Pa}$ and 20 min for each successive shear stress. Observed rapid decreases in concentration with time at a given shear stress were indicative of depth-limited erosion, also known as Type I erosion (e.g. Sanford \& Maa 2001), for which the critical shear stress of the bed increases with depth. Background water, collected near the seabed from which the core was taken, was pumped into the chamber and withdrawn from an outlet in the lid to maintain the desired shear stress. The water that was pumped through the turbidity meter from the chamber was subsequently collected in a 21 flask and filtered for suspended particulate matter (SPM) and particle size analysis. The turbidity meter and SPM data were used to calculate erosion rate, CME, and the depth-dependent critical erosion shear stress $\left(\tau_{\mathrm{c}}\right)$ for each core using the Gust Chamber processing software and following the erosion formulations of Sanford \& Maa (2001), which allows $\tau_{c}$ to increase with depth, thus properly representing depth-limited erosion. For a complete description of the Gust chamber, its function, and calibration, see Gust \& Muller (1997), Tolhurst et al. (2000), and Stevens et al. (2007).

\section{4. $\mathrm{CME}$}

The mass eroded per unit area at each shear stress step was calculated by multiplying the SPM for each 
shear stress step minus the background SPM, which was determined by gravimetric filtration, by the total volume of water collected for each stress step, and then dividing by the area of the eroded surface $\left(0.0092 \mathrm{~m}^{2}\right)$. CME $\left(\mathrm{kg} \mathrm{m}^{-2}\right)$ was calculated as the sum of the masses eroded for each shear stress step. For a further description of CME, see Stevens et al. (2007) and Wiberg et al. (2013).

\subsection{Sediment analysis}

The top $0.5 \mathrm{~cm}$ of the bottom sediment collected by the slo-corer was sampled using a stainless steel spoonula. Organic matter percentages from bottom sediments were estimated using loss on ignition (LOI) by combusting the sediment at $450^{\circ} \mathrm{C}$ for $6 \mathrm{~h}$ (Kristensen 1990). Organic matter percentages from Gust erosion filtered samples were determined using LOI by combusting a GF/F filter with suspended sediment sample (Kristensen 1990). The before-minus-after combusted weight of the sediment divided by the total dry weight multiplied by 100 represents the total organic matter percentage of the sample. Organic matter flux values were determined based on a programmable sediment trap that collected up to 12 samples, each over $6 \mathrm{~h}$ periods, during the study. The samples were used to calculate an average flux in $\mathrm{g} \mathrm{m}^{-2} \mathrm{~d}^{-1}$ for the entire sampling period. The sediment trap was tied off to an outer cage and sat on the seabed with the top of the trap approximately $1.4 \mathrm{~m}$ off the bottom.

The disaggregated inorganic grain size (DIGS) of the bottom sediments was determined for both the cohesive and non-cohesive sediments. Organic matter was removed by adding $35 \%$ hydrogen peroxide $\left(\mathrm{H}_{2} \mathrm{O}_{2}\right)$ to the sample. Samples then were disaggregated with a sapphire-tipped ultrasonic probe prior to analysis Grain-size analysis of cohesive samples from the Navy Island site were run on a Coulter Counter Multisizer 3 electro-resistance particle size analyzer (Milligan \& Kranck 1991, Law et al. 2008), and non-cohesive samples collected at the Jordan Bay site were analyzed using a Beckman Coulter LS 13320 laser diffraction particle size analyzer.

Bed solids volume fraction, $\phi_{\text {stot, }}$ was determined by dividing the volume of solids in the bed sediment by the total volume. The solids volume fraction of the mud matrix, $\phi_{\mathrm{sm}}$, in the bed sediment was determined based on the $<63 \mu \mathrm{m}$ fraction from the grain size analysis of bottom sediments using the Coulter Counter and Coulter Laser. For more information on $\phi_{\text {stot, }}$ and $\phi_{\mathrm{sm}}$, see Sanford (2008) and Dickhudt et al. (2011).

\subsection{Physical oceanography data}

An upward-looking Acoustic Doppler Current Profiler (ADCP; $2 \mathrm{MHz}$, Nortek Aquadopp) was deployed on a bottom-mounted frame at each aquaculture site, $100 \mathrm{~m}$ from the $0 \mathrm{~m}$ coring location. The ADCP was positioned $0.15 \mathrm{~m}$ above the seabed. Data were collected in burst mode at $8 \mathrm{~Hz}$ with 4800 samples. This frequency of sampling allowed data collection for 10 min every $30 \mathrm{~min}$ and enabled the measurement of current velocities and wave height, period, and orbital velocity. Shear velocities from currents were estimated using the law-of-the-wall equation. A wave-current-interaction model developed by Grant and Madsen was used to determine the combined wave-current shear stress at the seabed (Grant \& Madsen 1986, Madsen 1994). Roughness lengths, $z_{\mathrm{o}}$ were taken from Soulsby (1983, 1997 ) and were assigned values of $2.0 \times 10^{-4} \mathrm{~m}$ for mud and $4.0 \times 10^{-4} \mathrm{~m}$ for sand. Significant wave heights were collected using an RBRduet temperature and depth, wave gauge sampling at $16 \mathrm{~Hz}$ with 2048 samples per burst every $5 \mathrm{~min}$, which was mounted at $0.5 \mathrm{~m}$ above the seabed. An RBR CTD XR-620 sensor configured to make measurements of salinity, temperature, and pressure every $5 \mathrm{~min}$ by averaging data collected at $6 \mathrm{~Hz}$ for $30 \mathrm{~s}$ was colocated with the RBRduet.

\subsection{Statistics}

Statistical analyses were performed in SigmaStat of the SigmaPlot graphics software, which is a part of the Systat software package. Spearman correlations were used to test for correlation between sediment variables after the data were tested for normality using a Shapiro-Wilks test. Two-way ANOVA was carried out using station distance and time of sampling as the variables and using data for CME and organic matter percent for both the Jordan Bay and Navy Island locations (SigmaPlot 14, Systat Software). Post hoc comparisons both between and within variables based on significance of interactions was carried out using a Holm-Sidak test (SigmaPlot 14). Significance of interaction was also explored using Student-Newman-Keuls and Bonferroni tests. These tests revealed similar interactions, so only Holm-Sidak results are presented. 

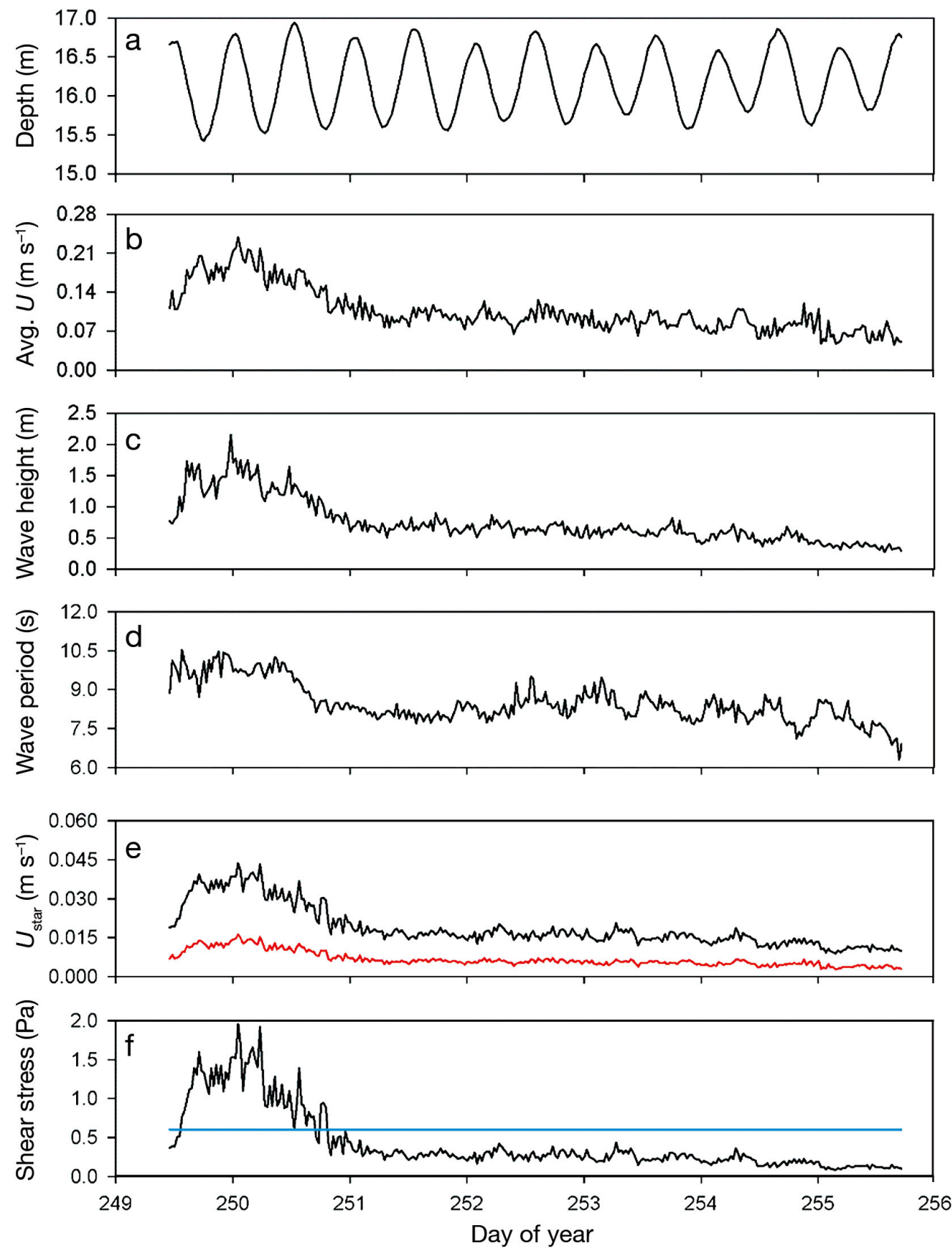

Fig. 2. Jordan Bay physical oceanography data from September 2016 from near cage. (a) Change in water depth from the CTD; (b) average current speed $(U)_{i}$ (c) significant wave height; (d) wave period; (e) calculated combined wave current shear velocity $\left(U_{\text {star}}\right)($ black) and current only shear velocity (red); (f) calculated shear stress (black) and the maximum shear stress of the Gust chamber erosion experiments (blue)

\section{RESULTS}

\subsection{Physical oceanography}

Seabed shear stresses at Jordan Bay were dominated by wave activity (Fig. 2). In September 2016, seabed shear stress averaged $0.42 \mathrm{~Pa}$. Stress re- mained above $0.08 \mathrm{~Pa}$ for the length of the study, and it was greater than $0.24 \mathrm{~Pa}$ for over $50 \%$ of the deployment period (Fig. 2). Seabed shear stresses at Navy Island were dominated by the tide (Fig. 3). During the October 2016 field campaign, bottom shear stress averaged 0.039 Pa and remained under 0.08 Pa for $>93 \%$ of the deployment period. Seabed shear 

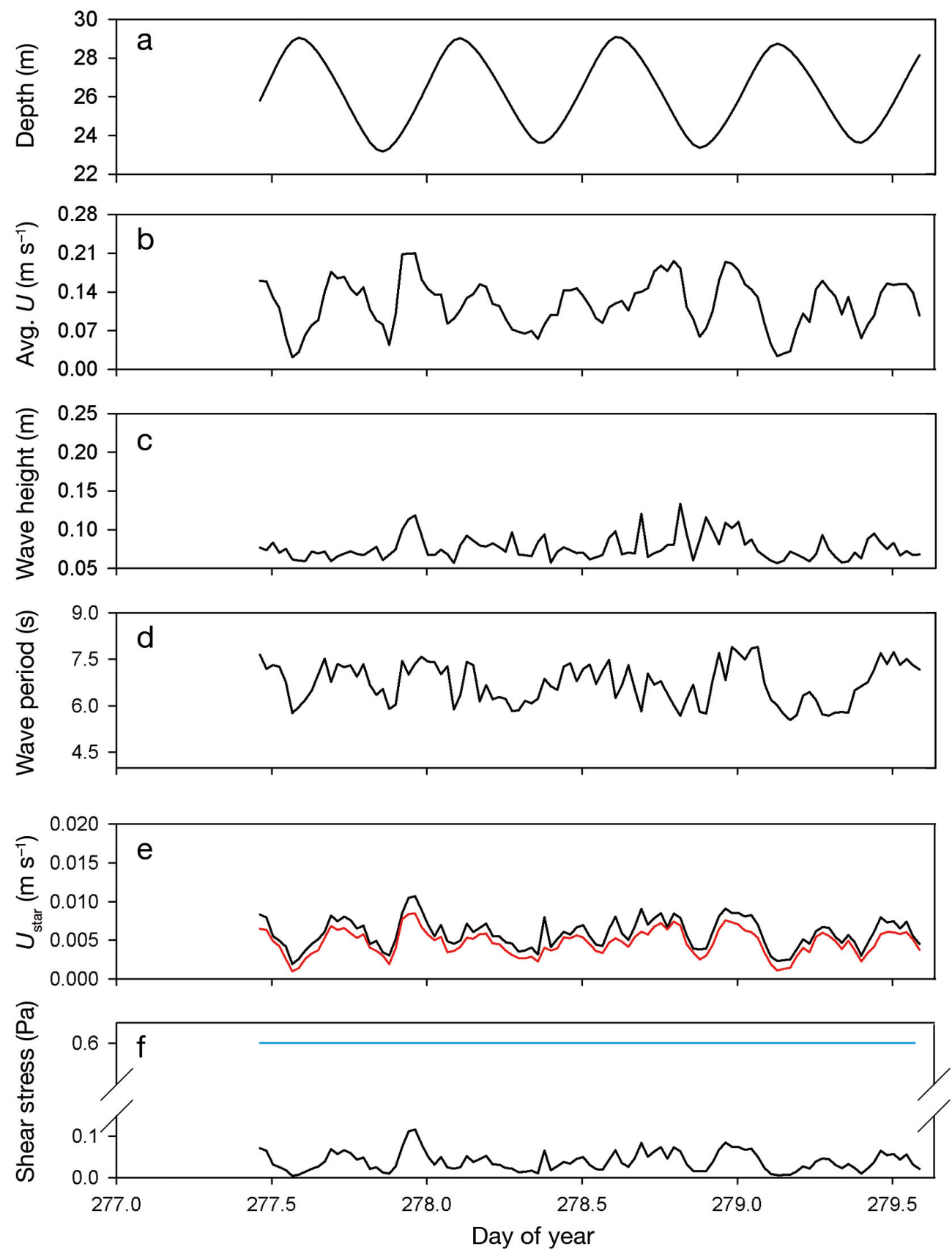

Fig. 3. Navy Island physical oceanography data from October 2016 from near cage. (a) Change in water depth from the CTD; (b) average current speed $(U)_{i}(\mathrm{c})$ significant wave height; $(\mathrm{d})$ wave period; (e) calculated combined wave current shear velocity $\left(U_{\text {star }}\right)($ black) and current only shear velocity (red); (f) calculated shear stress (black) and the maximum shear stress of the Gust chamber erosion experiments (blue)

stress at both study locations had similar values for the other study time periods compared with the last 2016 sampling. Significant wave heights at Navy Island are very small compared to Jordan Bay, ranging from 0.03 to $0.13 \mathrm{~m}$ with an average of $0.07 \mathrm{~m}$ (Fig. 3), whereas significant wave heights in Jordan Bay were sometimes in excess of $2 \mathrm{~m}$ (Fig. 2). As a result of such small wave heights, orbital velocities from waves were often negligible at the Navy Island site. Current velocities at both Jordan Bay and Navy Island were similar with maximum current velocities of approximately $0.20 \mathrm{~m} \mathrm{~s}^{-1}$ (Figs. 2 \& 3). Salinity was more variable at the Navy Island site compared to Jordan Bay over the 3 study periods and ranged from 
a low of 30.7 PSU in May 2015 to a maximum of 32.7 PSU in October 2016 with an average of 31.8 PSU, whereas Jordan Bay had an average salinity of 31.3 PSU which varied by less than 0.5 PSU over the 3 study time periods.

\subsection{CME}

Critical surface erosion shear stress, defined herein as the stress at which material was initially resuspended from the surface, was determined to be 0.01 to $0.02 \mathrm{~Pa}$. In both Jordan Bay, which is an area with a non-cohesive sediment seabed, and Navy Island, which is an area with a cohesive seabed, the initial erosion of material occurred at low shear stress. Visual observation of material eroded from the different bottom substrates suggests that flocculated particles dominated at lower shear stresses (i.e. 0.01 and

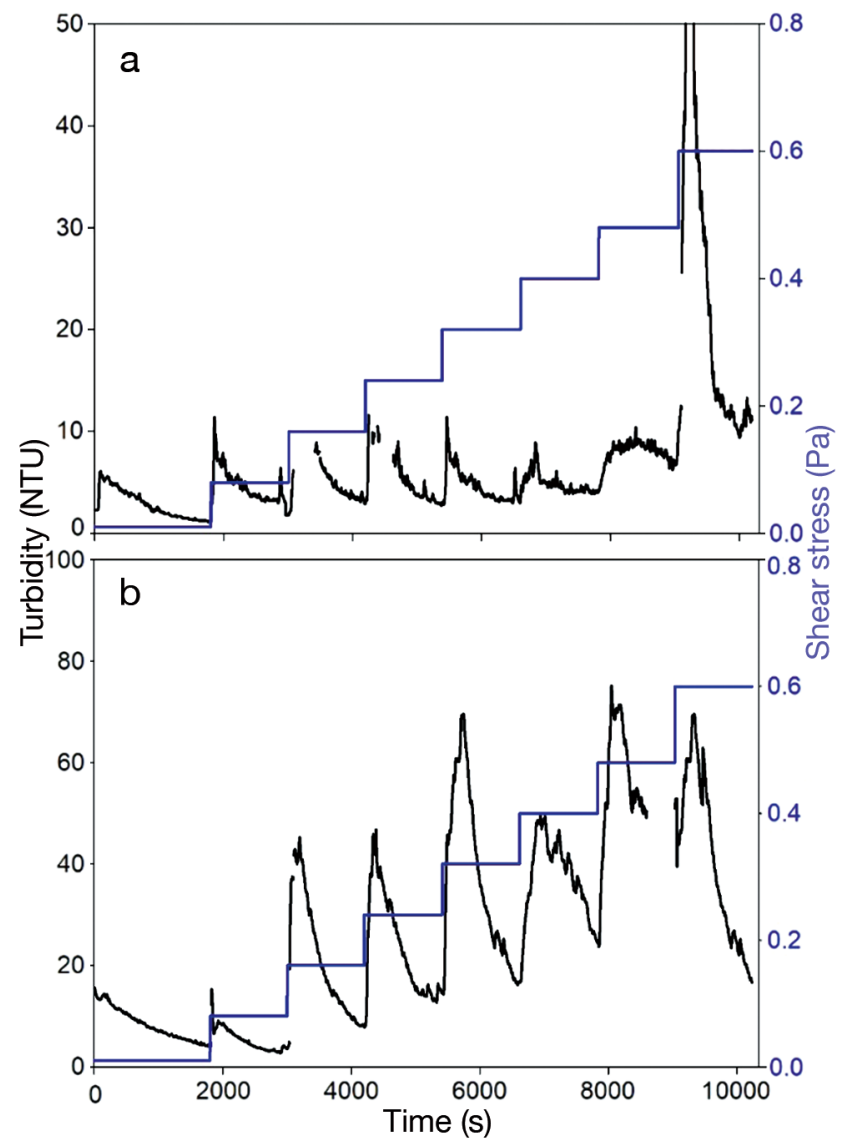

Fig. 4. Turbidity and applied shear stress versus time from the Gust chamber erosion experiments. (a) Typical erosion experiment from Jordan Bay with the bulk of mass being eroded in the last 2 shear stress steps. (b) Typical erosion experiment from Navy Island where mass eroded is similar over the shear stress steps. NTU: nephelometer turbidity units
$0.08 \mathrm{~Pa}$ ). The primary difference in erodibility of bottom substrate between the sites was that at the noncohesive site, little erosion occurred over all but the last 2 steps (i.e. 0.48 and $0.60 \mathrm{~Pa}$ ), whereas at the cohesive site, a similar amount of material eroded over each consecutive stress step (Fig. 4).

The CME at Jordan Bay from the $0 \mathrm{~m}$ stations on either side of the cage was always about an order of magnitude less during the June 2015 and September 2015 sampling and 5 times lower in the September 2016 sampling compared to the $1000 \mathrm{~m}$ station (Fig. 5, Table 1). At the initial site visit to Navy Island in May 2015, all stations had similar CME, with the

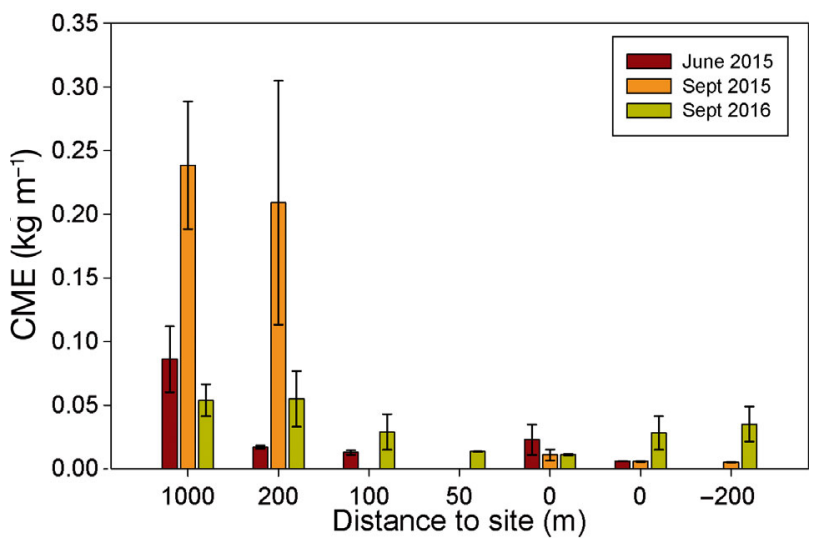

Fig. 5. Jordan Bay cumulative mass eroded (CME) from all samplings. The sample stations are in the direction of mean flow and represent distance from the site with the $0 \mathrm{~m}$ stations representing the opposite sides of the cage site. See Fig. 1 for more detail on sampling layout. Error bars: 1 SD

Table 1. Average CME values for Jordan Bay. Please see Fig. 1 for detail on sample layout

\begin{tabular}{|lccc|}
\hline $\begin{array}{l}\text { Distance } \\
(\mathrm{m})\end{array}$ & $\begin{array}{c}\text { Avg. CME } \\
\left(\mathrm{kg} \mathrm{m}^{-2}\right)\end{array}$ & $\begin{array}{c}\text { SD } \\
\left(\mathrm{kg} \mathrm{m}^{-2}\right)\end{array}$ & Date \\
\hline 0 & 0.0230 & 0.0119 & Jun-15 \\
100 & 0.0130 & 0.0017 & Jun-15 \\
200 & 0.0172 & 0.0014 & Jun-15 \\
1000 & 0.0862 & 0.0259 & Jun-15 \\
B0 & 0.0063 & 0.0001 & Jun-15 \\
0 & 0.0111 & 0.0043 & Sep-15 \\
200 & 0.2091 & 0.0957 & Sep-15 \\
1000 & 0.2384 & 0.0501 & Sep-15 \\
B0 & 0.0061 & 0.0004 & Sep-15 \\
B200 & 0.0054 & 0.0002 & Sep-15 \\
0 & 0.0113 & 0.0007 & Sep-16 \\
50 & 0.0138 & 0.0002 & Sep-16 \\
100 & 0.0292 & 0.0140 & Sep-16 \\
200 & 0.0551 & 0.0218 & Sep-16 \\
1000 & 0.0540 & 0.0125 & Sep-16 \\
B0 & 0.0283 & 0.0132 & Sep-16 \\
B200 & 0.0352 & 0.0137 & Sep-16 \\
\hline
\end{tabular}




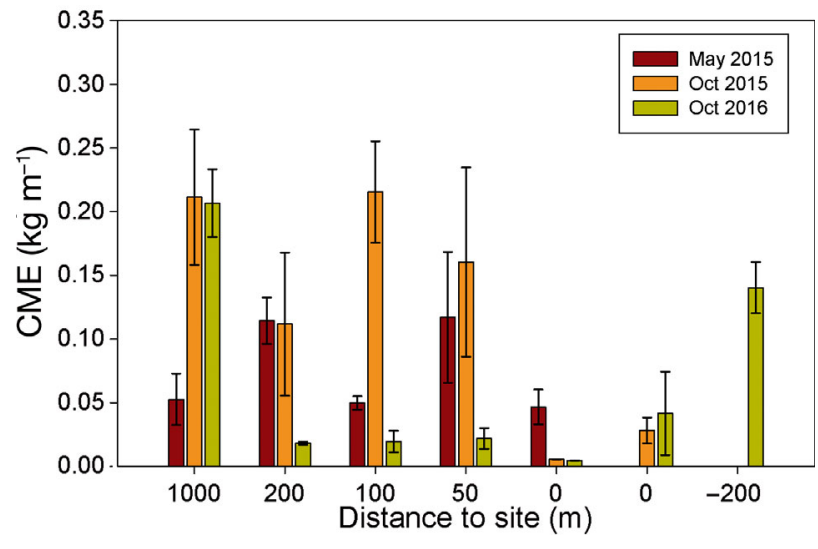

Fig. 6. As in Fig. 5, but for Navy Island. Please see Fig. 1 for detail on sample layout

Table 2. Average CME values for Navy Island

\begin{tabular}{|lccc|}
\hline $\begin{array}{l}\text { Distance } \\
(\mathrm{m})\end{array}$ & $\begin{array}{c}\text { Avg. CME } \\
\left(\mathrm{kg} \mathrm{m}^{-2}\right)\end{array}$ & $\begin{array}{c}\mathrm{SD} \\
\left(\mathrm{kg} \mathrm{m}^{-2}\right)\end{array}$ & Date \\
\hline 0 & 0.0467 & 0.0137 & May-15 \\
50 & 0.1171 & 0.0512 & May-15 \\
100 & 0.0499 & 0.0053 & May-15 \\
200 & 0.1144 & 0.0181 & May-15 \\
1000 & 0.0527 & 0.0202 & May-15 \\
0 & 0.0056 & 0.0001 & Oct-15 \\
50 & 0.1605 & 0.0742 & Oct-15 \\
100 & 0.2155 & 0.0398 & Oct-15 \\
200 & 0.1118 & 0.0562 & Oct-15 \\
1000 & 0.2114 & 0.0531 & Oct-15 \\
B0 & 0.0283 & 0.0101 & Oct-15 \\
0 & 0.0047 & 0.0002 & Oct-16 \\
50 & 0.022 & 0.0082 & Oct-16 \\
100 & 0.0196 & 0.0085 & Oct-16 \\
200 & 0.0182 & 0.0011 & Oct-16 \\
1000 & 0.2067 & 0.0265 & Oct-16 \\
B0 & 0.0417 & 0.0327 & Oct-16 \\
B200 & 0.1404 & 0.0200 & Oct-16 \\
\hline
\end{tabular}

$50 \mathrm{~m}$ station eroding approximately 2 times more than the 0 and $1000 \mathrm{~m}$ stations (Fig. 6, Table 2) In subsequent sampling periods in October 2015 and again in October 2016, there was a greater than an order of magnitude difference in CME between the 0 and $1000 \mathrm{~m}$ stations, with the $0 \mathrm{~m}$ stations eroding significantly less mass (Fig. 6, Table 2).

\subsection{Sediment characteristics}

Although the range of the mass fraction of sand (i.e. fs sand) in bottom sediments at Jordan Bay shifted slightly, it averaged $91 \%$ for each of the 3 sampling periods (Table 3 ). In addition, while the mud fraction
Table 3. Jordan Bay sediment characteristics, measured on 3 sampling dates. $\phi_{\text {stot }}$ : bed solids volume fraction; fs sand: mass fraction of sand; $\phi_{\mathrm{sm}}$ : solids volume fraction of mud matrix; $<63 \mu \mathrm{m}$ : mud fraction; <4 $\mu \mathrm{m}$ : clay content; na: not available

\begin{tabular}{|lccc|}
\hline & Max. & Min. & Avg. \\
\hline Jun 2015 & & & \\
Water content (\%) & 26.2 & 19.7 & 21.8 \\
$\phi_{\text {stot }}$ & 0.8 & 0.74 & 0.78 \\
fs sand & 0.94 & 0.87 & 0.91 \\
$\phi_{\text {sm }}$ & 0.30 & 0.19 & 0.24 \\
$<63 \mu$ m (\%) & 12.9 & 6.4 & 8.91 \\
$<4 \mu \mathrm{m}(\%)$ & 1.33 & 1.01 & 1.16 \\
Organic content (\%) & 0.86 & 0.47 & 0.57 \\
Sep 2015 & & & \\
Water content (\%) & na & na & na \\
$\phi_{\text {stot }}$ & na & na & na \\
fs sand & 0.94 & 0.87 & 0.91 \\
$\phi_{\text {sm }}$ na & na & na \\
$<63 \mu$ m (\%) & 13.2 & 6.40 & 8.80 \\
$<4 \mu \mathrm{m}(\%)$ & 2.02 & 1.00 & 1.25 \\
Organic content (\%) & 1.19 & 0.48 & 0.63 \\
Sep 2016 & & & \\
Water content (\%) & 31.3 & 21.3 & 28.6 \\
$\phi_{\text {stot }}$ & 0.77 & 0.69 & 0.71 \\
fs sand & 0.94 & 0.85 & 0.91 \\
$\phi_{\text {sm }}$ & 0.31 & 0.13 & 0.19 \\
$<63 \mu$ m (\%) & 15.9 & 6.40 & 9.20 \\
$<4 \mu \mathrm{m}(\%)$ & 1.71 & 0.93 & 1.13 \\
Organic content (\%) & 1.79 & 0.50 & 0.63 \\
\hline
\end{tabular}

(i.e. $<63 \mu \mathrm{m}$ ) in some bottom sediment samples increased over the 3 study periods from June 2015 to September 2016, the minimum amount remained constant over the 3 samplings, resulting in very little change to the average mud fraction (Table 3). The parameters $\phi_{\text {stot }}$ and $\phi_{\text {sm }}$ are representative of the bed solids volume fraction and of the solids volume fraction of the mud matrix, respectively, and are parameters used in the modelling of bed erosion and deposition processes. Indicative of a sandy environment, $\phi_{\text {stot }}$ averaged 0.78 in June 2015 and 0.71 in September 2016, while the average value of $\phi_{\mathrm{sm}}$ was 0.24 in June 2015 and 0.19 in September 2016 (Table 3).

At Navy Island, fs sand was always between 0 and $4 \%$ and averaged 1, 1 and $2 \%$ during the May 2015, October 2015 and October 2016 study periods (Table 4). The mud fraction (i.e. $<63 \mu \mathrm{m}$ ) ranged from 96 to $100 \%$ in the bottom sediment samples and averaged approximately $99 \%$ over the 3 study periods (Table 4). Indicative of a muddy environment, $\phi_{\text {stot }}$ averaged 0.37 in May 2015, 0.40 in October 2015, and 0.35 in October 2016, while the average value of $\phi_{\text {sm }}$ was 0.37 in May 2015, 0.39 in October 2015, and 0.34 in October 2016 (Table 4). 
Table 4. Navy Island sediment characteristics. See Table 3 for definitions

\begin{tabular}{|lccc|}
\hline & Max. & Min. & Avg. \\
\hline May 2015 & & & \\
Water content (\%) & 67.6 & 56.9 & 63.1 \\
$\phi_{\text {stot }}$ & 0.43 & 0.35 & 0.37 \\
fs sand & 0.02 & 0.000 & 0.01 \\
$\phi_{\text {sm }}$ & 0.43 & 0.32 & 0.37 \\
$<63 \mu$ (\%) & 100 & 98.3 & 99.3 \\
$<4 \mu$ m (\%) & 26.1 & 22.9 & 24.4 \\
Organic content (\%) & 5.80 & 5.36 & 5.55 \\
Oct 2015 & & & \\
Water content (\%) & 69.1 & 53.1 & 61.6 \\
$\phi_{\text {stot }}$ & 0.47 & 0.33 & 0.40 \\
fs sand & 0.02 & 0.00 & 0.01 \\
$\phi_{\text {sm }}$ & 0.47 & 0.33 & 0.39 \\
$<63 \mu$ (\%) & 100 & 97.7 & 98.7 \\
$<4 \mu$ m (\%) & 25.8 & 20.3 & 22.3 \\
Organic content (\%) & 7.50 & 5.60 & 6.30 \\
Oct 2016 & & & \\
Water content (\%) & 69.8 & 61.7 & 65.9 \\
$\phi_{\text {stot }}$ & 0.38 & 0.30 & 0.35 \\
fs sand & & \\
$\phi$ sm & 0.04 & 0.00 & 0.02 \\
$<63 \mu$ (\%) & 0.38 & 0.30 & 0.34 \\
$<4 \mu$ m (\%) & 100 & 96.3 & 98.5 \\
Organic content (\%) & 26.1 & 20.8 & 23.0 \\
& 8.60 & 5.74 & 6.88 \\
\hline
\end{tabular}

\subsection{Two-way ANOVA (Holm-Siddak) and Spearman correlations}

Two-way ANOVA was performed to examine the interactions of sampling distance from the center of the aquaculture cage sites and sample date on CME. At Jordan Bay, there was a significant effect of station distance $\left(F_{3,12}=23.16, \mathrm{p}<0.001\right)$ and sample date $\left(F_{2,23}=14.63, \mathrm{p}<0.001\right)$ on CME (Table 5). Post hoc analysis of interactions showed significant differences in CME among stations were driven largely by station distance within the September 2015 sampling. At Navy Island, there was also a significant effect of station distance $\left(F_{4,15}=3.979, \mathrm{p}<0.021\right)$ and sample date $\left(F_{2,15}=5.55, \mathrm{p}<0.016\right)$ on $\mathrm{CME}$ (Table 6). Post hoc analysis of interactions showed significant differences in CME only among the stations at 0 and $1000 \mathrm{~m}$.

Spearman correlations, the measure of strength of linear associations between variables, were run for each of the sediment characteristics from the bottom sediments collected at Jordan Bay and Navy Island (Tables $7 \&$ 8). The sediment data were combined over all 3 sampling periods. Values of CME were negatively correlated with the percentage of organics found in the muddy bottom sediments at Navy
Table 5. ANOVA for cumulative mass eroded for Jordan Bay

\begin{tabular}{|lccccc|}
\hline Source & df & SS & MS & $F$ & $p$ \\
\hline Station distance & 3 & 0.0672 & 0.0224 & 23.016 & $<0.001$ \\
Sample date & 2 & 0.0285 & 0.0142 & 14.63 & $<0.001$ \\
Distance $\times$ Date & 6 & 0.052 & 0.00867 & 8.902 & $<0.001$ \\
Residual & 12 & 0.0117 & 0.000974 & \\
Total & 23 & 0.159 & 0.00693 & \\
\hline
\end{tabular}

Table 6. ANOVA for cumulative mass eroded for Navy Island

\begin{tabular}{|lccccc|}
\hline Source & df & SS & MS & $F$ & $p$ \\
\hline Station distance & 4 & 0.0583 & 0.0146 & 3.979 & 0.021 \\
Sample date & 2 & 0.0406 & 0.0203 & 5.55 & 0.016 \\
Distance $\times$ Date & 8 & 0.0708 & 0.00885 & 2.418 & 0.067 \\
Residual & 15 & 0.0549 & 0.00366 & & \\
Total & 29 & 0.225 & 0.00775 & & \\
\hline
\end{tabular}

Island $(\mathrm{R}=-0.695, \mathrm{p}<0.001)$ (Table 8). The negative correlation coefficient means that as the percentage of organics in bottom sediments increased, the amount of mass eroded in the erosion experiments decreased.

Organic matter flux measured from the sediment trap approximately doubled at both locations over the study periods (Fig. 7). To further investigate the interactions of sample distance from aquaculture operations and sample date on organic matter percentage in the bottom sediment, a 2-way ANOVA was performed. At Jordan Bay, there was a significant effect of station distance $\left(F_{5,36}=15.97, \mathrm{p}<0.001\right)$ and sample date $\left(F_{2,36}=12.582, \mathrm{p}<0.001\right)$ on percentage of organics in bottom sediments (Table 9). Post hoc investigation of interactions revealed that stations immediately at the cage site, on both the north and south sides, experienced increases in organic matter percentage over the course of the sampling period (i.e. from May 2015 to September 2016) and that the stations at $0 \mathrm{~m}$ on both sides of the cage site were significantly different from the other stations (Fig. 8). At the Navy Island site, there was also a significant effect of sample distance $\left(F_{4,30}=24.563\right.$, $\mathrm{p}<0.001)$ and sample date $\left(F_{2,30}=51.042, \mathrm{p}<0.001\right)$ on organic matter percentage (Table 10). Investigation of interactions revealed that there was significant difference in organic matter percentage of the bottom sediment at the 0,50 , and $100 \mathrm{~m}$ stations compared to the 200 and $1000 \mathrm{~m}$ stations. In addition, there was a significant increase in organic matter percentage of bottom samples from the first sampling in June 2015 to October 2015 and then again to the 
Table 7. Jordan Bay Spearman correlations. ${ }^{*} p<0.05 ;{ }^{* *} p<0.01 ;{ }^{* * *} p<0.001$. The pairs of variables with positive correlation coefficients and p-values tend to increase together, and, for the pairs with negative correlation coefficients and p-values, one variable tends to decrease while the other increases. See Table 3 for definitions

\begin{tabular}{|c|c|c|c|c|c|c|c|}
\hline & $\phi_{\text {stot }}$ & $\begin{array}{l}<63 \mu \mathrm{m} \\
\text { fraction }\end{array}$ & $\begin{array}{c}\text { fs } \\
\text { sand }\end{array}$ & $\phi_{\mathrm{sm}}$ & $\begin{array}{c}<4 \mu \mathrm{m} \\
(\%)\end{array}$ & $\begin{array}{c}\text { Organic } \\
\text { content }(\%)\end{array}$ & $\begin{array}{c}\mathrm{CME} \\
\left(\mathrm{kg} \mathrm{m}^{-2}\right)\end{array}$ \\
\hline Water content $(\%)$ & $-1.000^{* * *}$ & -0.155 & -0.155 & $-0.778^{* * *}$ & -0.170 & $0.380^{* *}$ & 0.330 \\
\hline$\phi_{\text {stot }}$ & & -0.155 & -0.155 & $-0.778^{* * *}$ & 0.170 & $-0.380^{* *}$ & -0.330 \\
\hline$<63 \mu \mathrm{m}$ & & & $-1.000^{* * *}$ & $0.357^{*}$ & $0.648^{* * *}$ & 0.141 & 0.292 \\
\hline fs sand & & & & $0.357^{*}$ & $-0.648^{* * *}$ & -0.141 & -0.292 \\
\hline$\phi_{\mathrm{sm}}$ & & & & & $0.551^{* * *}$ & $-0.284^{*}$ & -0.096 \\
\hline$<4 \mu \mathrm{m}(\%)$ & & & & & & $0.361^{*}$ & -0.147 \\
\hline Organic content $(\%)$ & & & & & & & -0.064 \\
\hline
\end{tabular}

Table 8. Navy Island. As in Table 7, but for Navy Island

\begin{tabular}{|c|c|c|c|c|c|c|c|}
\hline & $\phi_{\text {stot }}$ & $\begin{array}{l}<63 \mu \mathrm{m} \\
\text { fraction }\end{array}$ & $\begin{array}{c}\text { fs } \\
\text { sand }\end{array}$ & $\phi_{\mathrm{sm}}$ & $\begin{array}{c}<4 \mu \mathrm{m} \\
(\%)\end{array}$ & $\begin{array}{c}\text { Organic } \\
\text { content }(\%)\end{array}$ & $\begin{array}{c}\mathrm{CME} \\
\left(\mathrm{kg} \mathrm{m}^{-2}\right)\end{array}$ \\
\hline Water content (\%) & $-1.000^{* * *}$ & -0.030 & -0.030 & $-0.990^{* * *}$ & $0.616^{* * *}$ & 0.263 & -0.259 \\
\hline$\phi_{\text {stot }}$ & & 0.030 & 0.030 & $0.990^{* * *}$ & $-0.616^{* * *}$ & -0.263 & 0.259 \\
\hline$>63 \mu \mathrm{m}$ & & & $-1.000^{* * *}$ & 0.052 & 0.104 & -0.244 & -0.115 \\
\hline fs sand & & & & -0.051 & -0.104 & 0.238 & 0.125 \\
\hline$\phi_{\mathrm{sm}}$ & & & & & $-0.607^{* * *}$ & $-0.280^{*}$ & 0.265 \\
\hline$<4 \mu \mathrm{m}(\%)$ & & & & & & -0.013 & -0.070 \\
\hline Organic content $(\%)$ & & & & & & & $-0.695^{* * *}$ \\
\hline
\end{tabular}

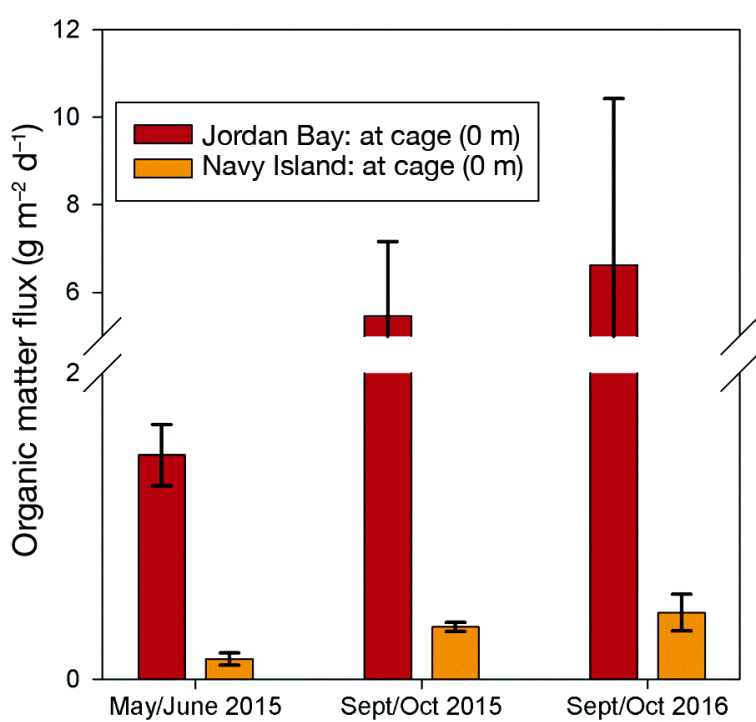

Fig. 7. Jordan Bay and Navy Island organic matter flux from all samplings. Error bars: $1 \mathrm{SD}$

final sampling in October 2016. Overall, stations from immediately at the cage site out to $200 \mathrm{~m}$ away from the cage on the sample transect showed significant change in terms of increased organic matter percentage from the start to the end of the samplings (Fig. 9).

\section{DISCUSSION}

\subsection{Near field vs. far field}

A significant increase in organic matter percentage in bottom sediments occurred at the cohesive sediment site, Navy Island, out to $200 \mathrm{~m}$ from aquaculture operations, from the beginning of the sampling when fish were added to the site until the end of sampling, which was just prior to fish being removed and sent to market. At the non-cohesive site at Jordan Bay, a significant increase in organic matter was observed only at the $0 \mathrm{~m}$ stations on both the north and south sides of the cage site over the 16 mo sampling period, during which fish grew from smolt to near market size. Organic matter flux $\left(\mathrm{g} \mathrm{m}^{-2} \mathrm{~d}^{-1}\right)$ collected at the time of each sampling approximately doubled at both locations during the grow out process (Fig. 7), with higher values observed at the Jordan Bay site. This difference may be due to the fact that the number of cages and subsequently the number of fish at the Jordan Bay site were higher than at the Navy Island site, with roughly 450000-600000 fish at Navy Island compared to 600000-1000000 fish at Jordan Bay, based on a standard stocking density of $30000-$ 50000 fish per cage (Cranford et al. 2017). Additionally, naturally occurring organic matter may be 
Table 9. ANOVA for organic concentration at Jordan Bay

\begin{tabular}{|lccccc|}
\hline Source & df & SS & MS & $F$ & $p$ \\
\hline Station distance & 5 & 2.27 & 0.454 & 15.97 & $<0.001$ \\
Sample date & 2 & 0.715 & 0.358 & 12.582 & $<0.001$ \\
Distance $\times$ Date & 10 & 0.368 & 0.0368 & 1.296 & 0.27 \\
Residual & 36 & 1.023 & 0.0284 & & \\
Total & 53 & 4.377 & 0.0826 & & \\
\hline
\end{tabular}

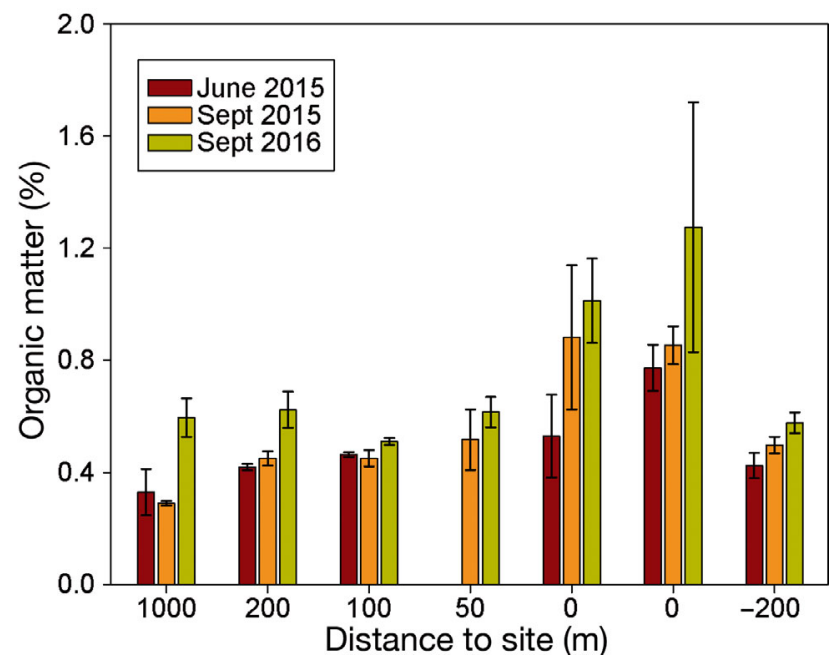

Fig. 8. Jordan Bay bottom sediment organic matter percentage from all samplings. The sample stations are in the direction of mean flow and represent distance from the site with the $0 \mathrm{~m}$ stations representing the opposite sides of the cage site. See Fig. 1 for more detail on sampling layout. Error bars: $1 \mathrm{SD}$

higher at the Jordan Bay site, although background water samples collected for the Gust erosion experiments from the stations adjacent to the cages at both locations had similar organic matter values of 10 to $20 \%$ of the filtered particulate matter, determined by LOI (authors' unpubl. data). Finally, resuspension may play a role in the observed higher organic matter at the more energetic Jordan Bay site.

Wave energy was greater at Jordan Bay. Higher energy was presumably responsible for greater dispersal of particulates coming from the aquaculture site, so organic enrichment was only detected directly under the site, where flux was largest. Farther away from the site, depositional flux was smaller than erosional flux, so the organic content of the seabed did not increase. At Navy Island, the erosional flux from waves and currents was low, so increased organic matter in the seabed was observed farther away from the aquaculture site. Increased sediment oxygen demand occurs at aquaculture sites as a result of increased deposition of organic matter (Har-
Table 10. ANOVA for organic concentration for Navy Island

\begin{tabular}{|lccccc}
\hline Source & df & SS & MS & $F$ & p \\
\hline Station distance & 4 & 8.781 & 2.195 & 24.563 & $<0.001$ \\
Sample date & 2 & 9.123 & 4.562 & 51.042 & $<0.001$ \\
Distance $\times$ Date & 8 & 4.428 & 0.554 & 6.193 & $<0.001$ \\
Residual & 30 & 2.681 & 0.0894 & & \\
Total & 44 & 25.014 & 0.568 & & \\
\hline
\end{tabular}

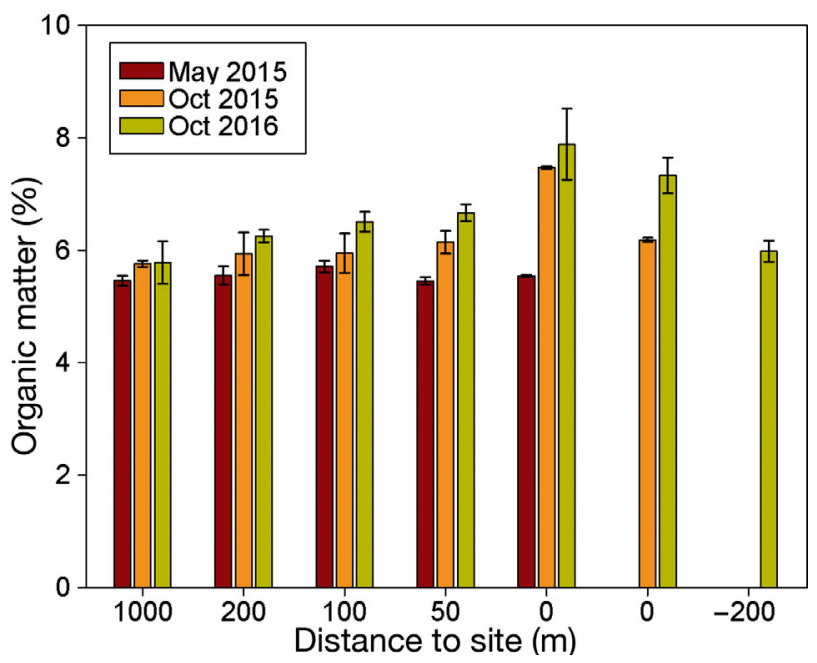

Fig. 9. As in Fig. 8, but for Navy Island

grave et. al. 1993, Droppo et al. 2007). Strain \& Hargrave (2005) estimated that up to $50 \%$ of organic matter deposited in the vicinity of salmon aquaculture cages at a cohesive site would be respired by the benthos. Grant et al. (1991) showed that areas of finegrained substrate had increases in organic content, bacterial biomass, and community metabolism, which led to a benthic oxygen demand of an average of 2.7 times that of coarser grained sand. Therefore, bacterial degradation and assimilative capacity of fine-grained sediments would be expected to be higher in the fine-grained cohesive sediments at the Navy Island site.

\section{2. $\mathrm{CME}$}

The erosion of material from cores collected in situ at both the Jordan Bay and Navy Island sites occurred at shear stresses as low as 0.01 to $0.02 \mathrm{~Pa}$, a value exceeded in situ at both locations, even by typical currents working on the seabed (Fig. $2 \& 3$ ). The material eroded was highly organic (i.e. 40 to $60 \%$ as determined by LOI, data not shown) at the 0.01 and 
$0.08 \mathrm{~Pa}$ shear stress steps, and visual observations indicated that it was flocculated. Milligan \& Law (2013) observed similar floc erosion of organic material from areas of active salmon aquaculture. As the stress increased in the erosion experiments from

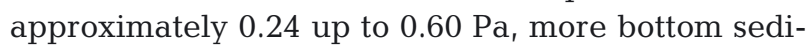
ment was eroded and the organic percentage in that sediment decreased. Even at the high shear stress steps (i.e. 0.48 and $0.60 \mathrm{~Pa}$ ), however, the organic matter percentage in the material eroded at both Jordan Bay at the $0 \mathrm{~m}$ stations to the north and south and at Navy Island stations out to $200 \mathrm{~m}$ on the main transect remained high (i.e. 10 to $15 \%$ ) compared with the bed sediments sampled with the slo-corer (Figs. 8 \& 9).

The Gust chamber erodes the most recently deposited bed material, which, because of the aquaculture at the sites, was higher in organic content than the background sediment. Dickhudt et al. (2011) estimated that only 1 to $2 \mathrm{~mm}$ of the bed sediment was eroded during erosion experiments performed in muddy environments with the same erosion device. Samples collected for organic matter analysis comprised approximately $0.5 \mathrm{~cm}$ of the top of the bed sediment, which may help to explain the increased organic matter percentage in Gust samples compared with the bed sediment values. In addition, research has shown that flow through permeable beds can transfer suspended particles from the boundary layer into surficial sediments (Huettel et al. 1996, Chen et al. 2010). This material may have been available for resuspension in the erosion studies, thereby enriching the Gust samples in organic matter.

DEPOMOD (now referred to as AutoDEPOMOD) is a model that was developed in the late 1990s to predict the solid waste accumulation on the seabed associated with fish farming activity (Cromey et al. 2002a). While primarily addressing the initial deposition of waste, AutoDEPOMOD also employs a simple resuspension module to redistribute waste particles according to near-bed currents (Cromey et al. 2002b). The resuspension module uses the erosion formula:

$$
M e=M\left(\frac{\tau_{b}}{\tau_{c}}-1\right)
$$

where, $M_{\mathrm{e}}$ is the erosion rate $\left(\mathrm{kg} \mathrm{m}^{-2} \mathrm{~s}^{-1}\right), \tau_{\mathrm{b}}(\mathrm{Pa})$ is the applied bottom stress, $\tau_{\mathrm{c}}(\mathrm{Pa})$ is the critical stress for erosion, and $M$ is an erodibility parameter $\left(\mathrm{kg} \mathrm{m}^{-2}\right.$ $\mathrm{s}^{-1}$ ). The value of $M$ governs the removal rate of material from the seabed when a bed stress greater than a critical stress is applied. In the module, the values of $M$ and $\tau_{\mathrm{c}}$ are set at $7.0 \times 10^{-7} \mathrm{~kg} \mathrm{~m}^{-2} \mathrm{~s}^{-1}$ and $0.0179 \mathrm{~Pa}\left(9.5 \mathrm{~cm} \mathrm{~s}^{-1}\right.$ flow speed), respectively. To compare AutoDEPOMOD predictions to observations, CME at each stress step was calculated by multiplying the modelled $M_{\mathrm{e}}$ for that step by the time over which that stress was applied (1200 s).

Based on our observations from this study, employing the standard AutoDEPOMOD parameter values overestimates the erosion of bottom material (Fig. 10). Chamberlain \& Stucchi (2007) also found that AutoDEPOMOD eroded too much mass, so they recommended that the resuspension module be turned off during simulations and that AutoDEPOMOD be used solely to determine the depositional footprint of aquaculture operation. When comparing AutoDEPOMOD output to measured sulfides, Chang et al. (2011) also found a similar result to that of Chamberlain \& Stucchi (2007).

Overestimation of CME by AutoDEPOMOD is linked to improper characterization of erosion. Sanford \& Maa (2001) proposed a linear formulation for erosion, with $\tau_{\mathrm{c}}$ as an increasing function of depth. This type of erosion limits the amount of sediment available at a given stress step, as observed in the erosion of cores in this study. According to the Sanford \& Maa (2001) formulation, more sediment becomes available for resuspension only by increasing the boundary shear stress. In AutoDEPOMOD, the mass transport of material continues at the rate governed by the erodibility parameter, $M$, as long as the critical bottom stress for erosion is exceed. An additional problem with AutoDEPOMOD is that all particle types (i.e. recently deposited flocs, fecal material, feed pellets) are assigned the same critical

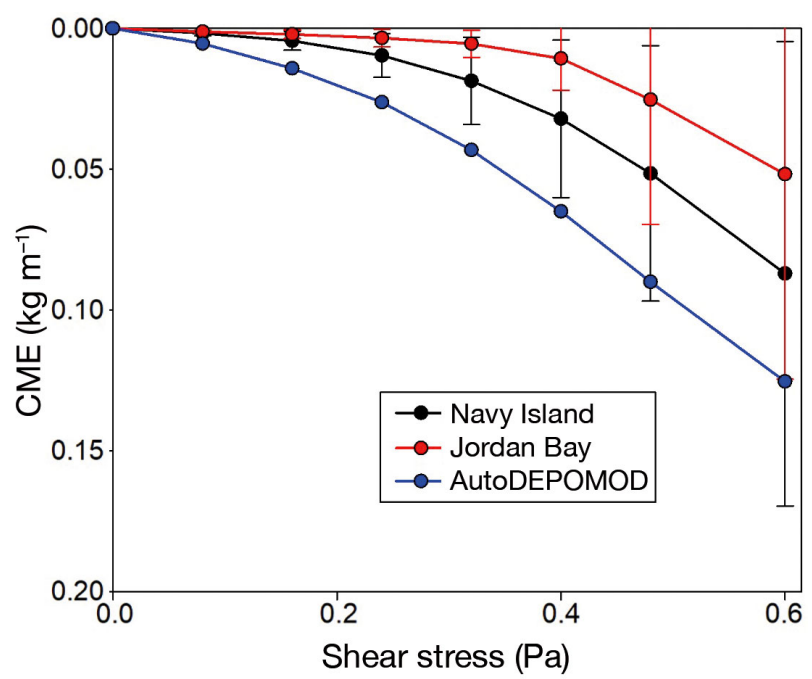

Fig. 10. Average cumulative mass eroded (CME) from Jordan Bay and Navy Island from all samplings. AutoDEPOMOD also shown as average CME using the AutoDEPOMOD erodibility parameter, $M$, set to $7.0 \times 10^{-7}$ 
stress for erosion. In recognition of these problems, NewDEPOMOD has been introduced, and it has an updated but unpublished resuspension module. This newer version of the model has not yet been incorporated into any of the various national regulatory processes.

\subsection{Modelling and transport}

Recent modelling efforts to understand and predict the transport of finfish waste, primarily salmon, from aquaculture operations to the near and far field have evolved mostly from single-point, near-field currents (Cromey et al. 2002a) to spatially explicit, 3D-current fields with higher resolution grids near farm sites (Wu et al. 2014, Bannister et al. 2016, Broch et al. 2017). Bannister et al. (2016) validated their coupled hydrodynamic-active particle-tracking model of organic waste dispersal in fjord systems by using observed particulate organic matter flux values from in situ sediment traps. They concluded that using fecal settling material values (i.e. $\mathrm{mm} \mathrm{s}^{-1}$ ) from variously sized fish improved predictions of deposition compared to a model with a single value for settling velocity (Cromey et al. 2002b).

Law et al. (2014) used in situ measurements to hypothesize that farm-produced particles packaged in flocs that settle at roughly $1 \mathrm{~mm} \mathrm{~s}^{-1}$ can be transported to the far field. Broch et al. (2017) used a coupled hydrodynamic-mass transport model to simulate the dispersal and deposition of fish farm waste (i.e. fecal material) at 3 separate locations in Norway, including a fjord, an exposed coastal location, and a semi-exposed location. They included floc-derived material (i.e. smaller size $<2 \mathrm{~mm}$ ) with appropriate settling velocities. Using the DREAM model with resuspension to transport material, model output was significantly improved when compared to observations of waste/mud thickness collected as part of the Norwegian mandatory benthic surveys of fish farms (Broch et al. 2017). The DREAM model also included waves based on the wind field in the erosion process which was important in the costal exposed and semiexposed sites.

This study, based on observations of mass eroded at aquaculture sites from cohesive and non-cohesive farm sites, shows several important factors that should be considered in aquaculture waste transport modelling. First, the organic content of bed sediments affects erosion. Second, organic content of bed sediments near aquaculture operations increases when fish are present. Higher organic content in turn leads to lower erosion rates when the bed becomes enriched, which represents a positive feedback. The perturbation caused by the addition of fish increases organic matter concentration in the bed sediment, which leads to decreased erosion of bed material, and thereby a greater increase in organic matter until a maximum is reached or the organic supply is turned off. Third, the effect of increasing organic matter in bed sediments is diminished but does not vanish in non-cohesive sediments, such as the sandy seabed sediments at Jordan Bay. Finally, transport models need to include waves at sites such as Jordan Bay, because it is the erosive force of waves that increases seabed stress and ultimately resuspends material from the seabed, making it available to transport by currents. The erosion experiments in this study went up to $0.60 \mathrm{~Pa}$, which is representative of typical coastal settings and can erode up to several $\mathrm{mm}$ of the seabed. At times when wind waves are large and occur in aquaculture areas with exposed sites and shallower water, waves can be responsible for large resuspension and transport events. Figs. 2 \& 3 show the difference in seabed stress between an area that is dominated by tidally induced versus wave-induced stress, with the latter showing an order of magnitude increase. This difference could be responsible for eroding several $\mathrm{cm}$ into the seabed, thus removing and transporting large amounts of organic matter out of the area and subsequently resetting the seabed.

\subsection{Implications and way forward}

Understanding the mass transport of aquaculture waste material to the far field is important for the sustainability of the industry and its so-called 'social licence to operate' (Mather \& Fanning 2019). This concept recognizes that social risks to operations must be addressed, and to do so will require building informed public acceptance of the risks posed by waste inputs to the marine environment. Not only can improved understanding of far-field transport help with already established sites, but it can also help during the siting and permitting phase for new sites. Predicting the mass transport of waste products based on the erosion of bed material at a specific site will help answer questions related to smothering or environmental effects that could occur with sensitive habitat such as eelgrass or kelp forests.

Graydon et al. (2012) used feed pigments to determine an area of influence out to $1000 \mathrm{~m}$ from aquaculture operations, and they hypothesized that low 
concentrations of small, farm-derived particles may exist on a bay-wide scale. Law et al. (2014) showed that relatively organic-rich, densely packed, flocculated particles that are perhaps indicative of aquaculture waste material were present at aquaculture sites and suggested these particles as a pathway to the far field. The coupled hydrodynamic-transport modelling studies of Bannister et al. (2016) and Broch et al. (2017) showed that organic material from aquaculture operations can reach several $\mathrm{km}$ into the far field. As the use of particle-reactive chemical constituents to combat disease and other factors such as sea lice continue to be used in open-ocean aquaculture, it is even more important to understand waste transport and other transport pathways. Predictive modelling using 3D spatially explicit currents coupled with waves and sediment transport/particle transport models will need to be refined and validated. The use of tracers, such as fatty acids, stable isotopes, pigments, etc. combined with measurements of particle properties (e.g. settling velocity, critical stress for erosion) and hydrodynamics will be required to increase our predictive capacity and for model validation.

\subsection{CONCLUSION}

As the organic matter percentage retained in bottom sediments increased at 2 active aquaculture sites, the mass eroded decreased. A significant increase in organic matter percentage in bottom sediments occurred at both a cohesive and a noncohesive site over the time of the sampling, which corresponded to a period during which the aquaculture sites were first stocked with salmon smolt until just before fish were removed for market. At the cohesive site, the organic matter percentage in bottom sediment increased significantly out to $200 \mathrm{~m}$ from the site. At the non-cohesive site, a significant increase was detected only at the $0 \mathrm{~m}$ north and $0 \mathrm{~m}$ south locations, which were immediately adjacent to the cage site. At the non-cohesive site, waves during fall and winter storms could be responsible for large resuspension events. Understanding differences in the erodibility of cohesive and non-cohesive seabeds and implementing appropriate parameters for resuspension and transport in models will improve predictive capacity in the movement of aquaculturederived waste products.

Acknowledgements. Thanks to Vanessa Zions, Casey O'Laughlin and Emma Poirier for help with sample collection and sediment analysis. Thanks to Peter Cranford and
Lindsay Brager for help with logistics and sampling during the course of the Larger ACOM project. Thanks are also given to the captain and crew of the Canadian Coast Guard Ship (CCGS) 'Viola Davidson' for use of a great platform to collect samples and for providing assistance in gear deployments and retrieval.

\section{LITERATURE CITED}

Amos CL, Daborn GR, Christian HA, Atkinson A, Robertson A (1992) In situ erosion measurements on fine-grained sediments from the Bay of Fundy. Mar Geol 108:175-196

Amos CL, Feeney F, Sutherland TF, Luternauer JL (1997) The stability of fine-grained sediments from the Fraser River Delta. Estuar Coast Shelf Sci 45:507-524

* Bannister RJ, Johnsen IA, Hansen PK, Kutti T, Asplin L (2016) Near and far-field dispersal modelling of organic waste from Atlantic salmon aquaculture in fjord systems. ICES J Mar Sci 73:2408-2419

Black KS, Tolhurst TJ, Paterson DM, Hagerthy SE (2002) Working with natural cohesive sediments. J Hydraul Eng 128:2-8

Bothner MH, Buchholtz ten Brink M, Manheim FT (1998) Metal concentrations in surface sediments of Boston Harbor - changes with time. Mar Environ Res 45:127-155

* Broch OJ, Daae RL, Ellingsen IH, Nepstad R, Bendiksen EA, Reed JL, Senneset G (2017) Spatiotemporal dispersal and deposition of fish farm wastes: A model study from central Norway. Front Mar Sci 4:1-15

Chamberlain J, Stucchi D (2007) Simulating the effects of parameter uncertainty on waste model predictions of marine finfish aquaculture. Aquaculture 272:296-311

Chang BD, Page FH, Losier RJ, Mccurdy EP, MacKeigan KG (2011) Characterization of the spatial pattern of benthic sulphide concentrations at six salmon farms in southwestern New Brunswick, Bay of Fundy. Can Tech Rep Fish Aquat Sci 2915:1-30

Chen C, Packman AI, Zhang D, Gaillard JF (2010) A multiscale investigation of interfacial transport, pore fluid flow and fine particle deposition in a sediment bed. Water Resour Res 46:413-427

Cranford PJ, Brager L, Wong D (2017) A dual indicator approach for monitoring benthic impacts from organic enrichment with test application near Atlantic salmon farms. Mar Pollut Bull 124:258-265

Cromey CJ, Thomas TD, Black KD (2002a) DEPOMOD modeling the deposition and biological effects of waste solids from marine cage farms. Aquaculture 214:211-239

* Cromey CJ, Nickell TD, Black KD, Provost PG, Griffiths CR (2002b) Validation of a fish farm waste resuspension model by use of a particulate tracer discharged from a point source in a coastal environment. Estuaries 25: 916-929

* Dickhudt PJ, Friedrichs CT, Sanford LP (2011) Mud matrix solids fraction and bed erodibility in the York River estuary, USA and other muddy environments. Cont Shelf Res Suppl 31:S3-S13

* Droppo I, Jaskot C, Nelson T, Milne J, Charlton M (2007) Aquaculture waste sediment stability: implications for waste migration. Water Air Soil Pollut 183:59-69

Einstein HA (1950) The bed-load function for sediment transportation in open channel flows. Technical Bulletin No. 1026. United States Department of Agriculture, Washington, DC 
FAO (2018) The state of world fisheries and aquaculture 2018-Meeting the sustainable development goals. FAO, Rome

* Grant J, Gust G (1987) Prediction of coastal sediment stability from photopigment content of mats of purple sulphur bacteria. Nature 330:244-246

Grant J, Emerson CW, Hargrave BT, Shortle JL (1991) Benthic oxygen consumption on continental shelves off Eastern Canada. Cont Shelf Res 11:1083-1097

Grant WD, Madsen OS (1986) The continental shelf bottom boundary layer. Annu Rev Fluid Mech 18:265-305

Gaydon CM, Robinson SMC, Scheibling RE, Cooper JA (2012) Canthaxanthin as a potential tracer of salmon feed in mussels (Mytilus spp.) and sea urchins (Strongylocentrotus droebachiensis). Aquaculture 366-367:90-97

Gust G, Muller V (1997) Interfacial hydrodynamics and entrainment functions of currently used erosion devices. In: Burt N, Parker R, Watts J (eds) Cohesive sediments. Wiley, Chichester, p 149-174

Hargrave BT, Duplisea DE, Pfeiffer E, Wildish DJ (1993) Seasonal changes in benthic fluxes of dissolved oxygen and ammonium associated with marine cultured Atlantic salmon. Mar Ecol Prog Ser 96:249-257

Huettel M, Ziebis W, Forster S (1996) Flow-induced uptake of particulate matter in permeable sediments. Limnol Oceanogr 41:309-322

Kristensen E (1990) Characterization of biogenic organic matter by stepwise thermogravimetry (STG). Biogeochemistry 9:135-159

Law BA, Hill PS, Milligan TG, Curran KJ, Wiberg PL, Wheatcroft RA, (2008) Size sorting of fine-grained sediments during erosion: results from the western Gulf of Lions. Cont Shelf Res 28:1935-1946

Law BA, Hill PS, Maier I, Milligan TG, Page F (2014) Size, settling velocity and density of small suspended particles at an active salmon aquaculture site. Aquacult Environ Interact 6:29-42

Maa JPY, Sanford LP, Halka JP (1998) Sediment resuspension characteristics in Baltimore Harbour, Maryland. Mar Geol 146:137-145

Madsen OS (1994) Spectral wave-current bottom boundary layer flows. In: Coastal Engineering 1994. Proc 24th Int Conf Coastal Engineering Research Council, Kobe, Japan, p 384-398

Mather C, Fanning L (2019) Social licence and aquaculture: towards a research agenda. Mar Policy 99:275-282

Milligan TG, Kranck K (1991) Electroresistance particle size analyzers. In: Syvitski JPM (ed) Principles, methods, and application of particle size analysis. Cambridge University Press, New York, NY, p 109-118

Milligan TG, Law BA (2005) The effect of marine aquaculture on fine sediment dynamics in coastal inlets. In: Hargrave BT (ed) Environmental effects of marine finfish aquaculture. Handbook of environmental chemistry, Vol 5M. Springer, Berlin, Heidelberg, p 239-251

Milligan TG, Law BA (2013) Contaminants at the sedimentwater interface: implications for environmental impact assessment and effects monitoring. J Environ Sci Technol 47:5828-5834

Neu TR (1994) Biofilms and microbial mats. In: Krumbein WE, Paterson DM, Stal LJ, (eds) Biostabilization. Oldenburg University Press, Oldenburg, p 9-15

Panchang V, Cheng G, Newell C (1997) Modeling hydrodynamics and aquaculture waste transport in coastal Maine. Estuaries 20:14-41
Partheniades E (1962) A study of erosion and deposition of cohesive soils in salt water. PhD thesis, University of California, Berkeley, CA, p 182

Reid GK, Liutkus M, Robinson SMC, Chopin TR and others (2009) A review of the biophysical properties of salmonid faeces: implications for aquaculture waster dispersal models and integrated multi-trophic aquaculture. Aquacult Res 40:257-273

* Sanford LP (2008) Modeling a dynamically varying mixed sediment bed with erosion, deposition, bioturbation, consolidation, and armoring. Comput Geosci 34:1263-1283

* Sanford LP, Maa JPY (2001) A unified erosion formulation for fine sediments. Mar Geol 179:9-23

* Sarà G, Scilipoti D, Mazzola M, Modica A (2004) Effects of fish farming wastes on sedimentary and particulate organic matter origin in a southern Mediterranean area (Gulf of Castellammare, Sicily): a multiple stable isotope study $\left(\delta^{13} \mathrm{C}\right.$ and $\left.\delta^{15} \mathrm{~N}\right)$. Aquaculture 234:199-213

Shields A (1936) Application of the theory of similarity and turbulence research to bedload movement. Mitt Preuss Verssuchsanst Wasserbau Schiffbau 26:5-24

Smith JN, Yeats PA, Milligan TG (2005) Geochronologies for fish farm contaminants in sediments from Lime Kiln Bay, Bay of Fundy. In: Hargrave BT (ed) Environmental effects of marine finfish aquaculture. Handbook of environmental chemistry, Vol 5M. Springer, Berlin, Heidelberg, p 221-238

Soulsby RL (1983) The bottom boundary layer of shelf seas. In: Johns B (ed) Physical oceanography of coastal and shelf seas. Elsevier, New York, NY, p 189-266

Soulsby R (1997) Dynamics of marine sands. A manual for practical applications. Thomas Telford Publishing, London

* Stevens AW, Wheatcroft RA, Wiberg PL (2007) Sediment erodibility along the western Adriatic margin, Italy. Cont Shelf Res 27:400-416

Strain PM, Hargrave BT (2005) Salmon aquaculture, nutrient fluxes and ecosystem processes in southwestern New Brunswick. In: Hargrave BT (ed) Environmental effects of marine finfish aquaculture. Handbook of environmental chemistry, Vol 5M. Springer, Berlin, Heidelberg, p 29-57

* Tolhurst TJ, Black KS, Shayler SA, Mather S, Black I, Baker K, Paterson DM (1999) Measuring the in situ erosion shear stress of intertidal sediments with the cohesive strength meter (CSM). Estuar Coast Shelf Sci 49:281-294

Tolhurst TJ, Black KS, Paterson DM, Mitchener HJ, Termatt GR, Shayler SA (2000) A comparison and measurement standardization of four in situ devices for measuring the erosion shear stress of intertidal sediments. Cont Shelf Res 20:1397-1418

* van Ledden M, van Kesteren WGM, Winterwerp JC (2004) A conceptual framework for the erosion behaviour of sand-mud mixtures. Cont Shelf Res 24:1-11

Wiberg PL, Smith DJ (1987) Calculations of the critical shear stress for motion of uniform and heterogeneous sediments. Water Resour Res 23:1471-1478

*Wiberg PL, Law BA, Wheatcroft RA, Milligan TG, Hill PS (2013) Seasonal variations in erodibility and sediment transport potential in a mesotidal channel-flat complex, Willapa Bay, WA. Cont Shelf Res 60:S185-S197

Winterwerp JC (1989) Flow induced erosion of cohesive beds. A literature survey. Cohesive sediments report 25. Delft Hydraulics and Rijwaterstaat, Delft

WW Y, Chaffey J, Law B, Greenberg DA, Drozdowski A, Page F, Haigh S (2014) A three-dimensional hydrodynamic model for aquaculture: a case study in the Bay of Fundy. Aquacult Environ Interact 50:235-248 